\title{
KONTRIBUSI ZAKAT DALAM MENURUNKAN TINGKAT KEMISKINAN DI INDONESIA
}

\author{
Nurmayani \\ Surel : nurmayani111161@gmail.com
}

\begin{abstract}
ABSTRAK
Secara bahasa, zakat bermakna tumbuh dan bertambah. Adapun secara istilah, zakat adalah hak khusus, di dalam harta khusus, untuk golongan khusus, yang wajib ditunaikan denganmemenuhi syarat-syarat tertentu. Zakat akan mengembangkan harta, membersihkannya, serta menyucikan pemilik harta. Dengan zakat, keadilan masyarakat akan terealisasi, hati takkan terpenuhi dengan sifat kikir, tamak, pun tidak dengan sifat benci dan permusuhan. Zakat berarti memberikan bagian tertentu dari harta yang berkembang jika sudah sampai nishob untuk keperluan tertentu. Zakat merupakan rukun islam yang ketiga dan wajib dikeluarkan oleh seorang muslim. Berdasarkan jumlah populasi muslim di Indonesia, zakat memiliki potensi yang cukup besar. Namun kesadaran muslim di Indonesia untuk membayar zakat masih rendah. Oleh karena itu, hal inilah yang mendasari penulis mengangkat bagaimana kontribusi zakat dalam menurunkan tingkat kemiskinan di Indonesia.
\end{abstract}

Kata kunci : Zakat, Nishob, Kemiskinan

\section{PENDAHULUAN}

Indonesia merupakan negara yang terletak di antara dua benua dan dua samudera. Berdasarkan data dari Bank Dunia, jumlah penduduknya menempati peringkat ke empat terbanyak di dunia dengan jumlah mencapai 249,9 juta jiwa pada sensus tahun 2013. Selain itu Indonesia juga termasuk negara dengan penduduk mayoritas muslim. Belum lagi dengan fakta bahwa sumberdaya alam yang cukup melimpah, Indonesia seharusnya dapat menjadi negara maju terutama di kawasan Asia Tenggara. Akan tetapi, Indonesia masih digolongkan negara berkembang. Salah satu permasalahan serius yang masih dihadapi adalah kemiskinan. Kemiskinan merupakan kondisi saat suatu penduduk memiliki rata-rata pengeluaran per kapita per bulan di bawah garis kemiskinan. Badan Pusat Statistik mengelompokkan penduduk miskin berdasarkan dari kebutuhan makanan dan kebutuhan nonmakanan. Pada pasal 34 UUD 1945 ayat 1 disebutkan bahwa 'Fakir miskin dan anak terlantar dipelihara oleh negara'. Salah satu penyebab kemiskinan di Indonesia adalah tidk meratanya pembangunan yang diselenggarakan oleh negara sehingga hanya sebagian kelompok orang saja ang mendapatkan akses.

Adapun program-program yang sudah berjalan digagas oleh pemerintah untuk mengentaskan kemiskinan adalah Bantuan Langsung Tunai (BLT) dan berlanjut hingga saat ini, serta Dana Desa yang langsung diteruskan ke setiap desa sejak awal pemerintahan Presiden Joko Widodo dan program-program pemicu penerimaan pajak yang setiap 

tahunnya terus dikaji.

Adapun potensi lain untuk mengatasi kemiskinan adalah zakat. Zakat berarti memberikan bagian tertentu dari harta yang berkembang jika sudah sampai nishob untuk keperluan tertentu. Zakat merupakan rukun islam yang ketiga dan wajib dikeluarkan oleh seorang muslim.Berdasarkan jumlah populasi muslim di Indonesia, zakat memiliki potensi yang cukup besar. Namun kesadaran muslim di Indonesia untuk membayar zakat masih rendah. Oleh karena itu, hal inilah yang mendasari penulis mengangkat topik "Zakat Pengentas Kemiskinan". Penulis mencoba menilisik bagaimana kontribusi zakat dalam menurunkan tingkat kemiskinan di Indonesia.

Dasar-Dasar Zakat adalah :

- Allah berfirman, "Alif lam mim. Kitab ini tidak ada keraguan padanya, petunjuk bagi mereka yang bertakwa. Mereka yang beriman kepada yang gaib, yang mendirikan shalat, dan menafkahkan sebagian rezeki yang Kami anugerahkan kepada mereka." (Al-Baqarah: 1-3)

- "Dan tunaikanlah haknya pada hari memetik hasilnya (AlAn'am: 141)

- Perintah mengeluarkan zakat disebutkan Allah di banyak ayat di dalam Al-Qur'an. Perintah mengeluarkan zakat diiringi dengan shalat karena keagungan dan kedudukannya yang tinggi di dalam agama.
- Allah menyifati orang yang menolak mengeluarkan zakat dengan "musyrik". Firman-Nya, "Dan kecelakaan besar bagi orang-orang yang mempersekutukan-Nya. Orangorang yang tidak menunaikan zakat dan mereka kafir akan adanya akhirat." (Fushshilat: 67)

- Abu Bakr radhiallahuanhu menjadikan zakat sebagai hak baitulmal dan dia memerangi orang yang menentang zakat. Syariat pun mengancam penentang zakat dengan siksa dan penyitaan harta.

Nabi shalallahu'alaihi wasallam memerintahkan kepada Muadz pergi ke Yaman untuk menyampaikan tauhid, shalat, dan zakat kepada kaumnya serta memerintahkan kepadanya untuk mengambil zakat dari mereka dan memelihara kemuliaan harta mereka.Nabi menentang keras orang yang menentang zakat bahwa dia akan disiksa dengan harta yang dia miliki. Jika hartanya berupa hewan peliharaan maka hewannya akan menikam dan menanduknya. Jika hartanya berupa emas atau perak, dia akan dibuatkan baju dari baja kemudian dipanaskan di neraka hingga dengannya kedua pinggang, punggung, dan keningnya disetrika. Dia kemudian digiring di antara manusia dan dia akan menyaksikan perjalanannya, apakah ke neraka atau ke syurga. 
Secara bahasa, zakat bermakna tumbuh dan bertambah. Adapun secara istilah, zakat adalah hak khusus, di dalam harta khusus, untuk golongan khusus, yang wajib ditunaikan dengan memenuhi syaratsyarat tertentu. Zakat akan mengembangkan harta, membersihkannya, serta menyucikan pemilik harta. Dengan zakat, keadilan masyarakat akan terealisasi, hati takkan terpenuhi dengan sifat kikir, tamak, pun tidak dengan sifat benci dan permusuhan.

Syarat-syarat zakat: (1) Islam, (2) merdeka, (bukan budak), (3) nishab yang dimiliki sempurna, dan (4) haul (satu tahun) termasuk selain yang dikeluarkan dari umi. Zakat binatang adalah untuk binatang ternak yang dikembangkanbiakkan, digembala di tempat umum, dan sudah melebihi masa satun kepemilikan, sedangkan binatang yang dipelihara di dalam kandang maka tidak wajib zakat kecuali yang disiapkan untuk dijual.

Yang wajib dikeluarkan

untuk zakat adalah (1) binatang ternak berupa unta, sapi dan kambing, (2) perhiasan berharga berupa emas, perak dan yang sejenisnya berupa kertas berharga; dan (3) segala yang dikeluarkan dari bumi dengan ketentuan-ketentuan yang diambil dari berbagai dalil. Kewajiban zakat pada hasil tambang, banyaknya adalah seperlima. Ini berdasar hadist yang diriwayatkan oleh banyak ahli hadits, "Dalam hasil tambang (wajib zakat) seperlima Sebagian ulama menambahkan, wajib zakat pada madu Jika sudah mencapai (nishab) takarannya. Dalilnya adalah hadits Amru bin Syu'aib, dia berkata "Bahwa pada masa Rasulullah shalallahu 'alaihi wasallam, dari geriba-geriba madu diambil zakatnya; setiap sepuluh geriba satu geriba yang berukuran sedang." Dalil untuk domba atau kambing ialah dari Anas radhiallahuanhu, dia meriwayatkan bahwa Abu Bakr radhiallahuanhu menuliskan untuknya ketika dia diutus ke Bahrain:" Dengan menyebut nama Allah. Inilah kewajiban zakat yang telah Rasulullah shalallahu'alaihi wasallam wajibkan bagi kaum muslimin. Allah telah memerintahkan dengannya kepada Rasul-Nya." Sedangkan dasar kewajiban zakat sapi ialah hadits yang diriwayatkan oleh Mu'adz radhiallahuanhu, dia berkata, "Rasulullah mengutusku untuk mengambil zakat dari penduduk Yaman. Beliau memerintahkanku untuk mengambil (zakat) dari setiap tiga puluh ekor sapi, satu ekor sapi yang sudah berumur saru tahun dan satu ekor sapi burumur dua tahun untuk setiap empat puluh ekor sapi."

Zakat emas berdasar pada hadits Aiyah radhiallahuanhu dan Ibnu Umar dengan derajat marfu' bahwa nabi biasa mengambil zakat emas dari setiap 20 mitsqal sebesar $1 / 2$ mitsqal, yaitu 1/4 dari 1/10-nya. Dalil tentang zakat perak adalah hadits Anas radhiallahuanhu : “ (Zakat) untuk perhiasan sebesar 
seperempat dari sepersepuluh." Dasar dikeluarkannya zakat hasil bumi adalah firman Allah, "Hai orang-orang yang beriman, nafkahkanlah sebagian dari hasil usahamu yang baik-baik dan sebagian dari apa yang Kami keluarkan dari bumi untuk kamu." (Al-Baqarah: 267). Adapun dalil dari sunnah, Nabi bersabda: "(Kewajiban zakat) untuk semua (tanaman) yang tersirami air hujan dan mata air ialah sepersepuluh (sepuluh persen). Sedangkan (zakat) untuk yang disiram dengan pengairan ialah setengah dari sepersepuluh (lima persen)."Tidak ada kewajiban zakat untuk yang kurang dari lima wasaq. "Secara ijmak, diwajibkan pula zakat atas biji-bijian, gandum, kurma dan kismis.

Nabi menyebutkan tujuh golongan yang akan Allah naungi pada hari yang tidak ada naungan, kecuali naungan-Nya. Sabda beliau, “... Dan seseorang yang menyedekahkan sesuatu, dia menyembunyikannya hingga tangan kirinya tidak mengetahui apa yang dinafkahkan oleh tangan kanannya."Allah berfirman, "Sesungguhnya, zakatzakat itu hanyalah untuk orangorangfakir, orang-orang miskin, pengurus-pengurus zakat, para muallaf yang dibujuk hatinya, untuk budak, orang-orang yang berutang untuk jalan Allah, dan untuk mereka yang sedang dalam perjalanan sebagai suatu ketetapan yang diwajibkan Allah, dan Allah Maha Mengetahui lagi Maha Bijaksana." (At-Taubah: 60)
Kemiskinan menurut Wikipedia bahasa Indonesia adalah keadaan dimana terjadi ketidakmampuan untuk memenuhi kebutuhan dasar seperti makanan, pakaian, tempat berlindung, pendidikan, dan kesehatan. Kemiskinan dapat disebabkan oleh kelangkaan alat pemenuh kebutuhan dasar, ataupun sulitnya akses terhadap pendidikan dan pekerjaan. Masalah kemiskinan adalah masalah yang kompleks dan global. di Indonesia masalah kemiskinan seperti tak kunjung usai. masih banyak kita dapati para pengemis dan gelandangan berkeliaran tidak hanya di pedesaan bahkan di kotakota besar seperti Jakarta pun pemandangan seperti ini menjadi tontonan setiap hari. Kini di Indonesia jerat kemiskinan semakin parah. Jumlah kemiskinan di Indonesia pada Maret 2009 saja mencapai 32,53 juta atau 14,15 persen. Kemiskinan bukan sematamata persoalan ekonomi melainkan kemiskinan kultural dan struktural.

Hari Susanto

(2006) mengatakan umumnya instrumen yang digunakan untuk menentukan apakah seseorang atau sekelompok orang dalam masyarakat tersebut miskin atau tidak bisa dipantau dengan memakai ukuran peningkatan pendapatan atau tingkat konsumsi seseorang atau sekelompok orang. Padahal hakikat kemiskinan dapat dilihat dari berbagai faktor. Apakah itu sosial-budaya, ekonomi, politik, maupun hukum. 


\section{PEMBAHASAN}

Sejauh ini lembaga zakat di Indonesia yang sangat bervariatif baik yang dikelola oleh pemerintah maupun swasta, tetap masih belum mampu menurunkan tingkat kemiskinan. Jumlah lembaga zakat yang semakin membengkak, seharusnya linier dengan akses mudah para fakir miskin mendapatkan peningkatan kesejahteraan hidup mereka. Namun kenyataannya, jauh dari harapan dimana jumlah kemiskinan per September 2016 hasil rilis BPS masih berjumlah 27,76 juta atau setara dengan 10,7 persen total penduduk Indonesia. Jika melihat kepada angka-angka penurunan kemiskinan setiap tahunnya yang hanya sekitar 1 persen, ini membuktikan bahwa program zakat dengan berbagai variannya belum mampu meningkatkan kesejahteraan masyarakat.

Padahal, penerimaan zakat yang diklaim Badan Amil Zakat Nasional (Baznas) terus mengalami peningkatan setiap tahunnya. Baznas misalnya melaporkan, penerimaan zakat, infaq dan sedejah pada 2015 sebesar 3,65 triliun dan meningkat 37,45 persen pada tahun 2016 menjadi sebesar 5,01 triliun. Ketua Baznas, Bambang Sudibyo bahkan mengklaim akan menggenjot perolehan zakat pada tahun ini dengan target capaian sebesar 6 triliun. Penulis tidak begitu paham apakah angka-angka sebesar itu memang secara nyata telah berhasil meningkatkan kesejahteraan masyarakat menurunkan rasio kemiskinan negara. yang penulis ketahui adalah kebanyakan bantuan zakat hanya menyasar wilayahwilayah yang terjangkau, dan itupun spontanitas tidak dijalankan secara berkelanjutan.

Prinsip zakat dalam ajaran islam yang sesungguhnya adalah "membersihkan" harta seseorang yang telah bertransaksi selama satu tahun. Perputaran atau transaksi harta yang diperoleh selama proses perputaran itu akan bercampur dengan harta-harta kotor lainnya sehingga mengurangi nilai kebaikan dari harta yang kita peroleh. Kesadaran akan berzakat, semestinya berangkat dari asumsi harta yang dimiliki itu "kotor" dan harus dibersihkan melalui apa yang dinamakan zakat. Membersihkan harta melalui zakat, bisa dilakukan secara pribadi dengan menyalurkan zakat masing-masing kepada kalangan yang kurang mampu, atau dapat mempercayakannya kepada lembaga zakat yang diakui oleh negara.

Istilah "zakat" sendiri dalam sejarah bangsa Arab selaras dengan makna kata "annamaa" yang berarti "tumbuh" atau "berkembang". Orang-orang Arab kuno ketika menyebut terjadi peningkatan dalam bidang pertanian, misalnya berucap "zaka al-zar'a idza al-namaa" (telah tumbuh dan berkembang tanaman itu). Disinilah kemudian istilah "zakat" dipergunakan untuk menekankan lambang kesucian harta sekaligus perputaran harta yang 
diperoleh dari zakat yang telah "bersih" dapat dimanfaatkan untuk pertumbuhan kesejahteraan masyarakat. Zakat dengan demikian jelas mempunyai nilai-nilai filosofis, soal bagaimana harta itu dapat berkembang secara baik, adalah didasarkan dari sumbernya yang benar-benar bersih, karena jika tidak, perkembangan pegelolaan harta zakat, bisa ditunggangi "benalubenalu" yang mempersulit tumbuh dan berkembangnya harta dalam mengejar realisasi kesejahteraan masyarakat.

Keuangan Syariah ternyata dapat membantu pemerintah dalam pengentasan kemiskinan dan pemerataan pendapatan masyarakat melalui zakat dan wakaf sebagai sumber pendapatan keuangan syariah. Pasalnya, potensi zakat dan wakaf di Indonesia sangatlah besar. Berdasarkan data dar Badan Amil Zakat Nasional (Baznas), potensi zakat Indonesia mencapai Rp 217 triliun. Sedangkan potensi wakaf mencapai Rp 370 triliun. Kurang lebih sama dengan Penerimaan Negara Bukan Pajak (PNBP) atau dalam dolar sekitar 18 dolar AS/ tahun 2017 lebih dari 10 persen anggaran pemerintah. Ini sangat menjanjikan untuk pengentasan kemiskinan.

Melihat potensi zakat dan wakaf yang sangat besar, Menteri Perencanaan Pembangunan Nasional (PPN)/Kepala Bappenas, Bambang Brodjonegoro mengatakan, pemerintah akan mereformasi zakat guna pengentasan kemiskinan dan pemerataan pendapatan. Reformasi tersebut akan memperbaiki sistem manajemen zakat dan pendistribusian zakat. Dengan memperbaiki manajemen dan pendistribusian zakat maka akan dapat menolong program pemerintah. Program pemerintah dan lembaga zakat yang saling melengkapi dan memperkuat dapat lebih efektif mengentaskan kemiskinan.

Dalam mendukung reformasi zakat, pemerintah pula akan mempermudah cara membayar zakat. Sehingga masyarakat dapat dengan mudah membayar zakat atau istilahnya user friendly. Kemudian penyaluran dana zakat harus dilakukan secara terbuka atau transparan. Sehingga masyarakat dapat mengetahui ke mana daa zakat tersebut disalurkan. Komite Nasional Keuangan Syariah (KNKS) akan diarahkan untuk menjadi wadah yang dapat mengsinkronisasi berbagai program dan reformasi zakat tersebut.

Persoalan kemiskinan merupakan salah satu persoalan krisial yang tengh dihadapi oleh bangsa Indonesia saat ini, apalagi saat ini kondisi perekonomian global sedang mengalami krisis pangan dan krisis energi. Harga minyak dunia yang telah menembus 140 dolar per barel diperkirakan akan menambah jumlah orang miskin baru sebanyak 15 juta jiwa pada tahun ini. Keadaan tersebut diperparah lagi oleh kondisi riil perekonomian masyarakat yang terus mengalami penurunan. Berdasarkan kajian Tim Indonesia 
Bangkit, Upah riil petani pada tahun 2007 lalu mengalami penurunan sebesar 0,2 persen dibandingkan dengan tahun sebelumnya. Demikian pula dengan upah riil buruh bangunan, pembantu rumah tangga, dan tukang potong rambut yang masing-masing mengalami penurunan sebesar 2 persen, 0,5 persen dan 2,5 persen (Beik dan Hakiem, 2008)

Untuk mengantisipasi dampak perekonomian global yang antara lain berdampak pada kenaikan harga bahan bakar minyak, pemerintah telah menyiapkan sejumlah paket kebijakan, yang di antaranya adalah paket Bantuan langsung Tunai (BLT). Namun demikian, kebijakan BLT tersebut seringkali tidak efektif akibat koordinasi dan manajemen yang kurang baik. Untuk ini, diperlukan adanya sejumlah instrumen alternatif yang diharapkan dapat menjadi solusi terhadap masalah kemiskinan dan masalah-masalah ekonomi lainnya. Salah satu instrumen tersebut adalah zakat, infak dan sedekah.

Dalam sebuah hadits yang diriwayatkan Imam al-Asbahani dari Imam at-Thabrani, dalam kitab AlAutath dan Al-Shaghir, Rasulullah Shalallahu'alaihi wasallam bersabda yang artinya : "Sesungguhnya Allah Subhanahuwata'ala mewajibkan atas hartawan muslim suatu kewajiban zakat yang dapat menanggulangi kemiskinan. Tidaklah mungkin terjadi seorang fakir menderita kelaparan atau kekurangan pakaian, kecuali oleh sebab kebakhilan yang ada pada hartawan muslim Ingatlah, Allah Subhanahuwata'ala akan melakukan perhitungan yang teliti dan meminta pertanggungjawaban mereka dan selanjutnya akan menyiksa mereka dengan siksaan yang pedih". Hadits tersebut secara eksplisit menegaskan posisi zakat sebagai instrumen pengaman sosial, yang bertugas untuk menjembatani transfer kekayaan dari kelompok kaya kepada kelompok miskin. Hadits tersebut juga mengingatkan akan besarnya kontribusi perilaku bakhil dan kikir terhadap kemiskinan.

\section{SIMPULAN}

Problematika kemiskinan merupakan salah satu permasalahan mendasar yang saat ini dihadapi oleh bangsa Indonesia. Sejumlah kebijakan telah dikeluarkan pemerintah dalam mengatasinya. Namun demikian seringkali kebijakan-kebijakan tersebut tidak berjalan dengan baik. Untuk itu diperlukan adanya solusi alternatif, yaitu melalui pemamfaatan dan optimalisasi instrumen zakat. Hasil analisa ZIS (Zakat, Infaq, Sedekah) menunjukkan bahwa zakat mampu mengurangi jumlah keluarga miskin dari 84 persen menjadi 74 persen. Kemudian dari aspek kedalaman kemiskinan, zakat juga terbukti mampu mengurangi kesenjangan kemiskinan dan kesenjangan pendapatan, yang diindikasikan oleh penurunan nilai dari $\mathrm{Rp} 540.657,01$ menjadi $\mathrm{Rp} 410.337,06$ dan nilai dari 
0,43 menjadi 0,33. Sedangkan ditinjau dari tingkat keparahan kemiskinan, zakat juga mampu mengurangi tingkat keparahan kemiskinan yang ditandai dengan penurunan nilai dari 0,46 menjadi 0,33.Bukti yang tidak terbantahkan bahwa instrumen zakat memiliki potensi yang luar biasa. Untuk itu, diperlukan adanya komitmen dan kerjasama yang kuat antar seluruh pemangku kepentingan zakat, baik pemerintah, DPR, badan dan lembaga amil zakat, maupun masyarakat secara keseluruhan dalam mewujudkan pembangunan zakat yang berkelanjutan. Mudahmudahan kajian di tingkat mikro ini dapat menjadi stimulus bagi kajiankajian serupa di tingkat yang lebih luas lagi.

\section{DAFTAR RUJUKAN}

Abdul Aziz, Imam. 2014. Risalah Zakat. Raudhatulmuhibbin.

Ali. 2015. Fiqih Wanita. Solo: AQWAM, Anggota SPI (Serikat Penerbit Islam).

Hasan, Ali dan Salim. 2017. Zakat Fitri. Ibnumajjah.

Ibrohim, A. 2014. Fiqih Kontemporer Zakat. Maktabah ar-Rusyd

Muhammad. 2012. Zakat Fitrah. Indonesia

Roem Rowi, HM. 2014. Panduan Zakat. Surabaya: Lembaga Manajemen Infaq

Syamhudi, Kholid. 2016. Apakah Hutang Menghalangi Kewajiban Zakat. As-Sunnah Ed 